\title{
Advertising Strategies as a Determinant for Consumer Brand Preference in Osun State, Nigeria (An Insight of u.a.c Foods PLC)
}

\author{
${ }^{1}$ Haorayau Bolaji Babalola, ${ }^{2}$ Saheed Ademola Lateef, ${ }^{3}$ Dauda Ayodele \\ Morakinyo,
}

\author{
${ }^{1}$ Osun State University Nigeria \\ ${ }^{2}$ University Sultan Zainal Abidin (UniSZA). \\ ${ }^{3}$ Osun State University Nigeria \\ mobolajiige07@yahoo.com \\ latsad4real@yahoo.com \\ dauda.morakinyo@uniosun.edu.ng
}

\begin{tabular}{l}
\hline ARTICLE DETAILS \\
\hline History \\
Received : February \\
Revised Format $:$ March \\
Accepted : April \\
\hline
\end{tabular}

Keywords :

Advertising strategies, Consumer brand preference, advertising media, Nigeria

\begin{abstract}
S
Several companies spend enormous amounts on advertising and still claim indifference in sales volume. This seems to be based on a completely understandable reaction to the initiative. The problem might emanate from media channel or advertising strategy itself. The study therefore, investigated effect of advertising strategies on consumer brand preference with particular reference to UAC food plc Osogbo, Osun state. It examined the choice of advertising media on consumers' brand preference and also determined the relationship between publicity through celebrity endorsement and consumer brand preference of UAC foods plc. 140 questionnaires were administered to the target respondents using simple random sampling and correlation and multiple regression techniques were used to analyse the collected data via SPSS version 25 . Result from the study shows that advertising has a significant effect on consumers' brand preference. Publicity through celebrity endorsement also has strong relationship with consumers' brand preference. The choice of advertising media has a significant influence on consumers' brand preference. The study therefore recommended that advertising should be seen as an investment in the future of products and not to be evaluated by its immediate returns.
\end{abstract}

\section{INTRODUCTION}

Several firms in Nigeria have over the years undermined the role of advertising in assessing consumer behavior and brand preference. Some companies spend enormous amounts of money on advertising and still claim indifference in sales volume (Bell \& Buchner, 2018). This misconception seems to be based on a completely understandable reaction to the initiative, how advertisers can assert that after a series of advertisements and huge money earmarked for it, advertising does not increase consumption and sales. De Vries, Gensler, and Leeflang, (2017) observed that advertising has significant influence on consumers, as well as volume of sales. Adverts may not necessarily result in a huge volume of sales in the short run, but if done properly, they will definitely increase sales in the long run.

Managers in the enterprises, however, advertise very well without scanning their environment, and that is the wrong advertisement. Even if some advertisers claim that accurate customer information, how they buy, why they buy and where they buy is unnecessary as it is 
possible to manipulate hapless consumers into splitting up their money for goods they don't want (Godey, Manthiou, Pederzoli, Rokka, Aiello, Donvito, \& Singh, 2016).

The primary aim of an advertiser is to reach out to potential customers and influence their awareness, behaviors, and purchase decisions. They invest a large amount of money in sustaining public interest in their goods (markets). To succeed, they must first understand why potential customers act the way they do. Marketers' goal is to collect enough relevant market data to create accurate buyer profiles in order to identify a common audience (and symbols) for communication, which entails studying consumer behavior: the mental and emotional processes, as well as the physical activities, of people who buy and use goods and services to meet specific needs and want to do so (Bell \& Buchner, 2018; Godey, et al., 2016). The core of every company outfit being in business is generating for sales and income. To remain in business, a company must sell enough of its goods to cover its operating costs and make a fair profit.

However, despite numerous empirical studies showing that the perception of advertising as a strong persuasive force is largely unfounded, models of advertising as a powerful force have persisted. The research aimed to examine the extent of advertising's effect on consumer brand preference in UAC products. Examine the effect of publicity on consumer brand preferences, finding advertising outlets that are most effective in shaping consumer purchasing behavior also explores the influence of celebrity endorsement on consumer brand choice, as well as identifying factors that promote consumer brand loyalty (Liu, \& Shankar, 2015).

Each advertisement strategy's ultimate goal is to influence the targeted audience's actual actions, whether it's purchasing intent or actual usage. If an advertisement campaign fails to achieve its target, it is not worth the significant amount of money spent on it. In this context, it's critical to explore UAC Foods Plc's entire advertising scenario, which is intertwined with the socio-cultural, economic, environmental, and commercial activities that shape customers' changing lifestyles (Liu, et al., 2018).

Similarly, UAC foods Plc consumers are exposed to several new products every other day, followed by advertising strategies from marketers (Oladepo \& Abimbola, 2015). It will therefore be interesting to investigate the effect of advertising on the behavior of consumers and UAC Foods Plc's brand preference. This research would be useful from a business perspective in understanding the mindset and attitudes of UAC Foods Plc's customers towards advertisements (Dehghani, Niaki, Ramezani, \& Sali, 2016). The aim of this research is to assess the effect of advertising on consumer behavior in a commercially viable market. It will assist in assessing the effectiveness of ads on customers, customer perceptions toward advertising, and the relationships between consumer demographics and advertising strategies in UAC Foods Plc's durables segment.

\section{Research Objectives}

The general objective of this study is to investigate the effect of advertising strategies on consumer brand preference and specifically;

i. To examine the choice of advertisement media on consumers' brand preference of UAC Foods Plc.

ii. To determine the relationship between publicity through celebrity endorsement and consumer brand preference of UAC Foods Plc.

iii. To examine the impact of advertisement channel on consumer brand preference of UAC Foods Plc. 


\section{LITERATURE REVIEW}

\section{Advertising and Brand Preference}

The predisosition of a customer toward a brand that varies based on the salient beliefs that are triggered at a given time point is referred to as brand preference (Mitchell \& Olson 1981). In general, for socially conscious brands, overall brand preference may not shift, and the definition of brand interest may be more important, particularly for existing brands with few prominent associated beliefs (Liu et al., 2018). Brand selection is a critical step in the decisionmaking process for consumers, since it includes elements of convenience. When it comes to brand preference, customers compare and rank various brands by concentrating on their individuality. Brand preference, according to Jin and Weber (2013), is "the degree to which the customer prefers the designed service provided by his or her current company over the specified service provided by other companies in its consideration set," with a consideration set referring to the goods that a consumer may consider buying in the near future. Customer recommendations also have a positive impact on brand and customer preferences (Gungor \& Bilgin, 2011).

Nonetheless, in categories where one would usually assume rich product-brand knowledge systems and thus some salient views, speaking about overall brand preference for mature brands may be misleading. Perhaps it's best to concentrate on relative brand preference, which can shift depending on which values are valid or which parts of the product-knowledge brand's system are activated (Chovanová, Korshunov, \& Babanová, 2015). As a result, for wellknown brands in mature product categories with multiple product attributes, it is preferable to measure relative rather than overall preference using a well-accepted multi-attribute preference measuring method (Green \&Srinivasan 1978). Generally, advertising's effects on attitudes are complex, and often indirect. Advertisements tend to be highly informative and pose many important product characteristics or features to the consumer which will lead to positive perceptions and can be used as the basis for legitimate brand choice. By the beauty it carries, the publicity it generates and the recognition it gives people get knowledge from the advertising (Arens, 2002).

One of the advertiser's main issues is whether the advertising or the commercial conveys the intended meaning. The recipient is seen as a very engaged, involved communications person whose capacity and enthusiasm to listen, interpret and analyze messages is high. If the customer or the listener gets the message and accepts it as the advertiser has it in mind, then the advertiser is a great success. The awareness leads people to like the brand and buy it (Clow \& Back, 2002). James Mundell (2006) indicated that advertisement has a significant effect on the preference of brand, regardless of whether it is being consumed with high or low attention rates. Very often, customers prefer to choose a brand they find to be in line with their self-image. In this particular way, each individual consumer should attempt by choice to represent his or her own identity. Consumer choices continue to adhere to a certain trend as part of a larger social group, thereby forming the basis for individual social identity (Catalin, Andreea, 2014).

\section{Advertising Strategy}

This is a technique that guides the advertiser in achieving the advertiser's objectives. According to Ehikwe (2006), an advertising strategy is needed to assess the specific marketing tasks that advertising would have to perform in the sale of a product. Every day, advertising budgets rise across the world, with new brands accounting for a large portion of this spending. Consumers believe that the amount of money spent on advertising represents the brand's efficiency (Liu, \& Shankar, 2015). More ads imply a higher level of product and service efficiency.

In this situation, marketers should build global strategies to improve the effectiveness and consistency of their advertising campaigns. Strong strategies can result in a variety of advantages, including lower advertising prices, improved global advertising coordination, and 
a more consistent image. Most foreign marketers consider the big picture when acting locally. According to them, the advertising software will conduct routine analyses of the touch and sales effect of advertisements (Liu, Sprott, Spangenberg, Czellar, \& Voss, 2018). They strive to make their promotional campaigns more responsive to local market consumer needs and preferences. UAC Foods, for example, has a range of promotional choices that can be used or customized to a variety of foreign markets. Others, such as the language of a variety of different countries, can only be used with small modifications.

\section{Brief Look into the Structure and Regulatory Controls of the Advertising Industry in Nigeria}

The advertiser, also known as the Consumer, is the first-party or central element in the advertisement trinity. The Advertiser is the driving force behind the advertising industry. Anyacho (2007) and Kessous, Roux, and Chandon (2015) describe the advertiser as a person, group, or company that offers goods, services, or ideas to the market for reasons that are ultimately beneficial to itself, and uses advertising to communicate this offer. The Nigeria Advertisers' Association is a commercial organization that depends on advertisement services to complement its marketing activities. Simply put, ADVAN is a trade group for advertisers (Oladepo \& Abimbola, 2015). This body was created for the following reasons: Customers started to see ads as valuable marketing support as advertising spending rose in the 1980s and 1990s, necessitating increased attention.

- The assumption of a dominant role by other arms of the advertising tripod.

- The increasing media rates became a source of concern, resulting in a call for concerted action by the sponsors of advertising, the clients.

Corporate agencies, licensed firms, government corporations, parastatals, and other law-making bodies using advertisement services in Nigeria are all eligible to join the Association. Nigeria Breweries Plc., MTN Nigeria, Zain Nigeria, WAMCO, Unilever Plc., ReckitBeckiser, GlaxoSmithKline (GSK), GlobacomNigeria, Nigeria Bottling Company Plc., 7 up Bottling Company, and other companies are members of ADVAN.

\section{Self-persuasion theory}

In the theory of self-persuasion, the degree of persuasion is related to the manner in which the recipients get involved and respond to the message. Those who follow this school of thought argue that recipients are engaged in advertising and elaborate on the message. We take an active role in deciding the purpose of the advertising and persuading them to back up, accept, derogate or deny the advice found in the message.

One example of self-persuasion theory is the elaboration-likelihood model proposed by Petty, Cacioppo, and Schumann (1985). When processing an advert (Wijaya, 2015), it posits three forces that cause recipients to elaborate in one of two ways ( Here the term "elaboration" implies issue relevant thinking about such aspects of the advert as its topics, arguments, implications, consequences, promises and execution element.

The three factors are motivation (i.e., the need for knowledge about brand-based benefits), the capacity or experience to understand the arguments and the willingness to evaluate benefit-based claims. The two routes to be established by the receivers are the main and peripheral routes (Liu, Sprott, Spangenberg, Czellar, \& Voss, 2018). If the receivers have the incentive, the skill and the capacity to process the information, they should follow the central route of processing the information, rationally making such direct benefit-based arguments as gas mileage or trunk space when dealing with the purchase of a vehicle, for example. Conversely, recipients will expand on peripheral clues (e.g. environment, originality, humor, and feelings conveyed) in and advertising when they lack incentive, skill, and capacity to evaluate reasonable benefit-based appeals. This model stresses the central premise of the theory of self-persuasion, persuasion relies on the contribution of the recipients to the message (Wijaya, 2015). 


\section{METHODOLOGY}

The quantitative case study of the descriptive research design was employed for this study. The population of the study consisted of customers of UACN Foods Plc in Osogbo, Osun State. Osogbo was chosen because of its large market size in Osun State and many firms use Osogbo to test market their new products. This research, therefore, covers the selected UACN Food Plc customers in Osogbo. A sample size of 140 was obtained from the population cut across entire customers of UACN Foods in Osogbo at 5\% error tolerance and 95\% degree of freedom using Krejice and Morgan (1970) statistical formula $140(100 \%)$ of the questionnaires distributed 104 were returned and 36 (26\%) were not returned. The questionnaire was designed in a Likert scale format. The researchers conducted a pre-test on the questionnaire to ensure the validity of the instrument. Correlations coefficient and regression analysis were used to test the hypotheses.

The reliability of the instrument was established by the test-retest method. The instrument was administered to 10 UACN staff, who were not part of the sample. After two weeks, the same instrument was re-administered to the same respondents and scores were taken. The two sets of scores were computed and correlated using Correlation coefficients ( $r$ ) and a reliability coefficient of 0.86 was obtained which was considered high enough for reliability. The internal-external validity was thereafter validated by experts in the field of measurement and evaluation.

\section{Data Analysis and Result}

\section{Correlation Test}

Correlation analysis is used to explain the strength and direction of a linear relationship between two variables (Pallant, 2010). Pearson correlation was employed to assess the interrelationship between study variables. Table 1 indicates the interrelations among advertising media choice, advertising, and publicity, advertising channel and brand preferences. Pallant (2010) asserted that a correlation of 0 indicated no relationship at all, a correlation of 1.0 is an indication of positive correlation, and the value of -1 is a pointer of a perfect negative correlation. Cohen (1988) suggested the following guidelines as: $r=0.10$ to 0.29 small; $r=0.30$ to 0.49 medium; and $\mathrm{r}=0.5$ to 1.0 large.

Table 1: Pearson Correlation Analysis of the Variables

\begin{tabular}{llllll}
\multicolumn{1}{c}{ Constructs } & AMC & ADV & PUB & ADC & BRP \\
\hline Advertising Media Choice & 1 & & & & \\
\hline Advertising & $.410^{* *}$ & 1 & & & \\
\hline Publicity & $.590^{* *}$ & $.653^{* *}$ & 1 & & \\
\hline Advertising Channel & $.622^{* *}$ & $.395^{* *}$ & $.513^{* *}$ & 1 & \\
\hline Brand Preferences & .481 & .398 & .562 & .421 & 1 \\
\hline
\end{tabular}

Table 1 signifies that the variables are significantly correlated to the fact that there is no variable with a value of 0.9 which indicated that there is no problem of multicollinearity (Hair et al., 2010).

\section{Regressions and Hypotheses Test}

\section{Regression Analysis and Hypotheses Test between the effect of Advertising strategies on consumer brand preferences}

Multiple regression analysis was conducted in determining the relationship between advertising strategies and consumer brand preference of UAC Foods Plc in Osun State.

Table 2: Model Summary ${ }^{b}$ 


\begin{tabular}{cccccc}
\hline Model & $\mathrm{R}$ & $\mathrm{R}$ Square & $\begin{array}{c}\text { Adjusted R } \\
\text { Square }\end{array}$ & $\begin{array}{c}\text { Std. Error of } \\
\text { the Estimate }\end{array}$ & $\begin{array}{c}\text { Durbin- } \\
\text { Watson }\end{array}$ \\
\hline 1 & $.684^{\mathrm{a}}$ & .507 & .502 & .36165 & 1.251 \\
\hline
\end{tabular}

a. Predictors: (Constant), advertising strategies

b. Dependent Variable: Consumer Brand Preferences.

The model summary as indicated in Table 2 shows that $\mathrm{R}$ Square is 0.51 ; this implies that $51 \%$ of the variation in the dependent variable (advertising strategies) was explained by the constant variables (Consumer brand preferences) while the remaining $49 \%$ is due to other variables that were not included in the model. This means that the regression (model formulated) is useful for making predictions.

Table 3: ANOVA ${ }^{\mathrm{a}}$

\begin{tabular}{llccccc}
\hline & Model & Sum of & Df & Mean Square & F & Sig. \\
\hline 1 & Regression & 29.832 & 4 & 14.916 & 114.046 & $.004^{\mathrm{b}}$ \\
& Residual & 329.035 & 222 & 3.131 & & \\
& Total & 358.866 & 224 & & & \\
\hline
\end{tabular}

a. Dependent Variable: consumer brand preference

b. Predictors: (Constant), advertising strategies

Table 3 summarized the findings of the study of variance in the dependent variable, which had a high regression sum of squares value (29.832) compared to the residual sum of squares, which was 329.035. This value suggested that the model is capable of explaining a significant portion of the variance in the dependent variables. However, the approximate Fvalue (114.046) in Table 3 with a significance value of 0.004 (p0.05) indicates that the explanatory variable elements as a whole will affect change in the dependent variable (consumer brand preferences).

Table 4: Coefficients ${ }^{\mathrm{a}}$

\begin{tabular}{lcccccc}
\hline \multirow{2}{*}{ Model } & \multicolumn{2}{c}{$\begin{array}{c}\text { Unstandardized } \\
\text { Coefficients }\end{array}$} & $\begin{array}{c}\text { Standardized } \\
\text { Coefficients }\end{array}$ & \multirow{2}{*}{$\mathrm{T}$} & \multirow{2}{*}{ Sig. } \\
\cline { 2 - 4 } & $\mathrm{B}$ & Std. Error & Beta & & \\
\hline (Constant) & .690 & .250 & & 2.758 & .006 \\
Advertising media & .247 & .059 & .191 & 4.186 & .000 \\
Advertising & .522 & .185 & .303 & 2.828 & .005 \\
Publicity & .899 & .289 & .433 & 2.015 & .006 \\
Advertising Channel & .487 & .248 & .437 & & 1.970 & .050 \\
\hline
\end{tabular}

a. Dependent Variable: Consumer Brand Preferences

Table 4 shows the dependent variable that illustrates the impact of advertising campaigns on customer brand preferences. This was used as a metric to assess the relationship between the two variables (i.e. advertising strategies). The advertisement media preference ttest coefficient is 4.186 , and the P-value is 0.000 , which is less than 0.05 (i.e. P0.05), as shown in Table 4.4. Furthermore, the advertisement t-test coefficient is 2.828 , with a P-value of 0.005 , which is less than 0.05 (P0.05). Similarly, the advertising t-test coefficient is 2.015 , with a Pvalue of 0.006, which is less than 0.05 (P0.05). Finally, the t-test coefficient for advertisement networks is 1.970 , with a P-value of 0.050 . This means that at a $5 \%$ significance level, these variables are statistically important. Overall, the coefficient of advertisement campaigns has an important effect on customer brand choice, according to the findings of this regression. This suggests that the null hypothesis will be dismissed, while the alternative hypothesis will be approved (i.e., advertising strategies have a significant influence on consumer brand preference). As a result, the hypotheses $\mathrm{H} 1-\mathrm{H} 3$ are sponsored. 


\section{Discussion of Findings}

The present study was conducted to examine the effect of advertising on consumer brand preference of UACN Food Plc. The result of the hypotheses tested shown that advertising has a significant effect on consumers' brand preferences. Consumers are exposed to thousands of adverts daily. It seems almost inevitable to avoid seeing/hearing any promotional marketing of a product or service. Based on the theory and objectives of this study, it can be analyzed that advertising affects consumer brand preference by making people buy more. The study supports Solomon (2002) who revealed that consumers seek information that makes marketing products easier and successful. Thus, people that recognize adverts and brands might consider purchasing a product more than a person that is being unconsciously exposed to advertising. The objective of the first research question is to identify various types of advertisement channel in UAC foods plc this research question reveal that UAC foods in the quest to be among the leading FMCG's in Nigeria have adopted several advertisement channels, such as TV, radio, internet advert, and outdoor advert.

Hypothesis one which states that Choice of Advertisement media does not have any significant effect on consumers brand preference was tested and the result shows that advertisement media has significant effect on consumers brand preference, hence, null hypothesis was rejected, This view has been supported by Sonkusanre (2013) and Rix (2007) who also concluded that TV, radio and magazines influences notably on consumer brand preference.

Hypothesis two which states that there is no significant relationship between publicity through celebrity endorsement and consumers' brand preference of UAC Foods Plc. The hypothesis was tested and it shows that publicity advertisement through celebrity endorsement has a positive relationship with consumers' brand preference, therefore null hypothesis was rejected. This was supported by Smita Sharma (2006), Goldsmith, Lafferty, and Newell (2000), Tyynela and Carroll (2008), they revealed that there is a significant relationship between publicity and consumer brand preference.

The third hypothesis, which states that advertisement channels, does not influence the consumer buying behavior of UAC foods. Advertising media are the communication channels that carry messages from advertisers to their advertising targets, which are, print, broadcast, direct mail, outdoor advertising (e.g., posters and printed bulletins, internet advertisement). The null hypothesis was rejected which shows that the choice of an advertising channel is very important. This is in agreement with, Pillai and Bagavathy (1998), John (2001), Vijaykumari (2002), Chunawalla and Sethia (2004); Sonkusare (2013). In this research study, regression and correlation test was employed to analyze the data. It should be noted that from the hypotheses tested the null hypotheses were rejected while the alternative hypotheses were accepted. Conclusively, the three hypotheses tested, null hypotheses were rejected while alternative hypotheses were accepted at 0.01 and 0.05 level of significance.

\section{CONCLUSIONS AND RECOMMENDATIONS}

Based on the findings, this paper concluded that advertisement has a positive effect on the consumer's choice of a brand. Advertising effectiveness can be seen as the extent to which advertising generates a certain desired effect, which is the urge to purchase a particular brand that can result in brand loyalty, thereby increasing the sales turnover of the company. Conclusively, the effectiveness of the advertisement can be attributed to a lot of factors which are publicity through celebrity endorsement, the choice of advertisement media and the channel of advertisement that will generate great attention of the targeted consumers.

The first hypothesis which explains that the choice of advertisement media has a positive effect on consumers' brand preference, this result is in conferment with Rix (2007), Sonkusan (2013) who also suspect that TV, radio and magazines. In general advertising media influences notably consumer brand preference. The second hypothesis concluded and the study 
shown that there is a significant relationship between publicity through celebrity endorsement and consumers' brand preference. The advertisement that features celebrity does increase the purchase decision of a particular brand. The result is consistent with previous research by Smita Sharma (2006); Goldsmith, Lafferty, and Newell (2000), Tyynela and Carroll (2008). It proved that celebrity endorsement in advertising will help increase the sales of a product brand.

Publicity sometime serves as a driven force propelling a consumer to decide on the choice of a brand. This hypothesis is in line with Win Janssens and Patrick (2005), David (2000). It should be noted that publicity has a relative effect on brand preference and consumer behavior. The third hypothesis concluded that the advertisement channel does influence consumer buying behavior. Advertising media are the communication channels that carry messages from advertisers to their target audience, which are, print, broadcast, direct mail, outdoor advertising e.g., posters and printed bulletins, internet advertisement. The advertisement channel is the medium in which the management of the company creates an awareness of its product to consumers. This hypothesis is in line with, Pillai and Bagavathy (1998), John (2001), Chunawalla and Sethia (2004), Vijaykumari (2002). From the result of the findings, it was seen that TV commercials are the form of advertisement channel that influences consumers brand preference and consumer behavior, this It may be that it's a powerful tool that uses audio and visual messaging to increase brand awareness.

Advertising was discovered to be a primary weapon in a firm's marketing decision variables and successful in the marketing of consumer goods in UAC foods products such as Gala sausage, fun-time cake, and coconut chips, as well as supreme ice cream, according to this report. As a result, the answer to the question "can ads be evaluated?" is an unequivocal affirmative. Every marketing variable in a business must be measured in terms of how well it contributes to the company's growth. Advertisement has been discovered to influence a consumer's view of a commodity in this research. As the market climate becomes more competitive and risky, companies are struggling as a result of bad decisions and low patronage. It's no wonder, then, that ads can help raise demand for a product by making it popular in customers' minds.

The following are some of the study's recommendations.

i. Ads should be regarded as an investment in the future of goods rather than a cost-benefit study.

ii. In the case of a crisis, companies do not cut their advertising budgets because advertising will help them regain their dignity. Consider goods like Phensic, Cafenol, and Bongo Tea, which are no longer available due to logistical difficulties and little or no ads. However, when it comes to the effect of ads, there should be a system of checks and balances in place.

iii. In order for the advertisement to be viable, the compromise must be abandoned, necessitating the use of core experts for proper preparation and execution of the advertisement rather than using quacks to save money.

iv. It's also a good idea to define a target market before you start advertising so you can find out which medium would be the most efficient and cost-effective for reaching them. Advertising an expensive car on a billboard, for example, would have little effect because 80 percent of the target market reads newspapers and watches cable television.

v. Prior to advertising, a detailed review of the advertising climate is required. This will concentrate on learning about the physical characteristics of different media options, as well as their strengths and weaknesses. Capacity to meet an audience; costeffectiveness.

vi. It is important to determine how well campaign goals were accomplished, for example, if the aim was to raise awareness, what is the current level of awareness?

vii. The advertisement's visuals, sentences, and sounds must be respectable and in good taste. 


\section{REFERENCES}

Anyacho R.C. (2007) Advertising: Principles \& Practice - the Nigerian Perspective: first ed. Lagos, Nigeria, Teejay Enterprises. pp 130,160.

Arens, W.F. (2002). Contemporary Advertising, 8th ed., Pearson Education Inc, India, pp.13.

Bell, R., \& Buchner, A. (2018).Positive effects of disruptive advertising on consumer preferences. Journal of Interactive Marketing, 41, 1-13.

Catalin, M. C., \&Andreea, P. (2014).Brands as a Mean of Consumer Self-expression and Desired Personal Lifestyle. Procedia - Social and Behavioral Sciences, 109, 103-107.

Chovanová, H. H., Korshunov, A. I., \& Babčanová, D. (2015).Impact of Brand on Consumer Behavior. Procedia Economics and Finance, 34, 615-621

Chunawalla, S.A.; and Sethia, K.C. (2004), Foundations of Advertising - Theory and Practice, pp.128.

Clow, K.E., \& R. Back. (2002). Integrated Advertising \& Marketing Communication, 2nd ed., Prentice-Hall, India, p.198.

Cohen, J. (1988). Statistics Power Analysis for the Behavioral Sciences, (2nded). New Jersey: Lawrence Erlbaum Associates.

David. (2000). Branding a B2B service: Does a brand differentiate a logistics service provider? Industrial Marketing Management, 37(2), 218-227.

De Vries, L., Gensler, S., \&Leeflang, P. S. (2017).Effects of traditional advertising and social messages on brand-building metrics and customer acquisition. Journal of Marketing, 81(5), 1-15.

Dehghani, M., Niaki, M. K., Ramezani, I., \& Sali, R. (2016). Evaluating the influence of YouTube advertising for the attraction of young customers. Computers in human behavior, 59, 165-172.

Ehikwe A.E. (2006) Advertising \& Other Promotional Strategies: Enugu, Nigeria, Precision Publishers Ltd. Pp 92.

Godey, B., Manthiou, A., Pederzoli, D., Rokka, J., Aiello, G., Donvito, R., \& Singh, R. (2016). Social media marketing efforts of luxury brands: Influence on brand equity and consumer behavior. Journal of business research, 69(12), 5833-5841.

Goldsmith, Lafferty, \&Newwell. (2000), Linking Attributes, Benefits, and Values: A Powerful Approach to Market Segmentation, Brand Positioning, and Advertising Strategy", Marketing Research, pages 3-8.

Green, Paul E. and V. Srinivasan (1978), "Conjoint Analysis in Consumer Research: Issues and Outlook," Journal of Consumer Research, pp.103-123.

Gungor, M. O. \&Bilgin, F. Z. (2011). Customer's Advisory, Organizational Openness, and Capability: the Locus of Value Creation. Eurasian Journal of Business and Economics, 4 (7), 81-97.

James M., John H. W. \& Dave W. (2006), High attention processing: the real power of advertising, Admap, July - August, pp.40-41.

John. (2001), TV as a media for advertising televisions. Indian Journal of Marketing.Vol.21 .p.21-26.

Kessous, A., Roux, E., \&Chandon, J. L. (2015). Consumer-brand relationships: A contrast between nostalgic and non-nostalgic brands. Psychology \& Marketing, 32(2), 187-202.

Krejcie, R. V., \& Morgan, D. W. (1970). Determining sample size for research activities Educational and psychological measurement 1970, 30, 607-6 10. 
Liu, R. L., Sprott, D. E., Spangenberg, E. R., Czellar, S., \& Voss, K. E. (2018). Consumer preference for national vs. private brands: The influence of brand engagement and selfconcept threat. Journal of Retailing and Consumer Services, 41, 90-100.

Liu, Y., \& Shankar, V. (2015). The dynamic impact of product-harm crises on brand preference and advertising effectiveness: An empirical analysis of the automobile industry. Management Science, 61(10), 2514-2535.

Oladepo, O. I. \& Abimbola, O. S. (2015).The influence of brand image and promotional mix on consumer buying decision-a study of beverage consumers in Lagos State, Nigeria. British journal of marketing studies, 3(4), 97-109.

Pallant, J. (2010). SPSS Survival Manual: A step - by step guide to data analysis using SPSS for Windows (version 15). Australia: Allan and Urwin.

Petty, C. \& Schumann, A. (1985). Central and peripheral routes to advertising effectiveness: The Moderating Role of Involvement", Journal of Consumer Research.

Pillai, B. \& Bagavathy, F. (1998). 'Marketing', S. Chand \& Company Ltd., Ram Nagar, New Delhi

Rix. D. (2007). Marketing; a practical approach, 6th ed. AU: McGraw Hill Australia Pty Limited.

Smita, S. (2006). Effect of Advertising Likeability: A 10Year Perspective. Journal of Advertising Research, 46(1).

Solomon. T. (2002) consumer behavior (5thed), upper saddle River, Nj. Prentice-Hall.

Sonkusare, T. (2013). Impact of television advertising on buying behavior of women consumers'[With special reference to FMCG Products] Chandrapur city. International Journal of Business and Management Invention, 2(3), 31-38.

Tyynela M. \& Carroll, W. (2008). Perceived quality levels and their relation to involvement, satisfaction, and purchase intentions. Marketing Bulletin, 16(4), 1-10.

Vijaykumari W. (2002). Why liking matters, Journal of Advertising Research, 34(3), 9-18.

Wijaya, B. S. (2015). The development of the hierarchy of effects model in advertising. International Research Journal of Business Studies, 5(1). 